\title{
The Africanist Delusion: In Defence of the Realist Tradition and the Neo-Neo Synthesis
}

\author{
Casper Hendrik Claassen \\ Department of Political Sciences, University of Pretoria, Pretoria, 0002, South Africa
}

Tel : 27-82-551-2722 E-mail: ch.claassen@gmail.com

\begin{abstract}
In this essay, the Africanist critique of mainstream International Relations (IR) theory and the neo-neo synthesis, and in particular the realist tradition, is critically analysed. It is argued that although the Africanist critique does highlight some pertinent issues, it ultimately fails to be convincing due to, firstly, its misunderstanding of the neo-neo synthesis and the realist tradition in particular; secondly, its disregard for human nature; and thirdly, its promotion of a stance that would lead to further marginalization. It is posited that although Africanists perceive globalisation as Westernisation - and Americanisation to be more specific - and interpret the aforementioned as essentially echoing the Foucauldian notion of a power-knowledge nexus, their interpretation does not necessarily undermine the realist tradition, but rather substantiates it. It is concluded that the realist tradition, specifically, has not led to Africa's marginalization - rather it is something which has been the result of mostly internal dynamics which have created external vulnerabilities.
\end{abstract}

Keywords: Africanist delusion, Sub-Saharan Africa, Neo-neo synthesis

\section{Introduction}

A thesis that has enjoyed growing popularity, and one primarily posited by Africanists, has been that traditional adherence to mainstream international relations (IR) theory - neo-realism, neo-liberalism, both positivist, and, to a lesser extent, Marxism and critical theory, both post-positivist - has led to the marginalization of sub-Saharan Africa (SSA) in world politics, and hence the global economy, by being Eurocentric and thus not considering the unique socio-cultural and socio-economic characteristics of SSA. This argument is based on either, depending on who is asked, the Coxian and Carrian assumption (Acharya \& Buzan, 2007: 300; Hobson, 2007: 92), as well as the ancient Greek concept of Phronesis, that social theory is always generated and employed for the benefit of "someone or some group, the spread of certain values, or for the achievement of some goal, such as von Bismarck's neo-mercantilism and the British Empire's use of liberalism, making it an inherently political activity, or the arguments of post-modernists who argue that theory is inadvertently created based on a certain Weltanschauung, so as to benefit someone, spread certain values, or to achieve some goal; to elaborate on the latter contention, it is argued that approaches to IR such as realism, liberalism, Marxism, the English School, constructivism, and postmodernism, et cetera all originated in the West, and are hence unavoidably Eurocentric (Acharya \& Buzan, 2007: 299-300; Hobson, 2007: 93). Both strands essentially submit that there is a nexus between author and theory, a constitutive assertion, and that the West has gained intellectual hegemony in the Gramscian sense (Hobson, 2007: 93) - as shown by the understanding of globalization as Westernization, and Americanization to be more specific. The aforementioned essentially echoes Foucault's notion of a power-knowledge nexus. Africanists have thus sought an intellectual revolution which might lead to the creation of a truly African theory of IR that would allow for the proper explanation and understanding of key problems and issues central to the international relations and politics of SSA and would perhaps also allow for the gradual placement of SSA at the centre of world politics, and perhaps the global economy, by, for instance, adopting the "correct" policies (Dunn, 2000: 89-91). The purpose of this assignment will hence be to evaluate the Africanist critique of mainstream IR theory and the Africanist dream of a truly African IR theory, and if any credibility is found, then a solution will be sought.

\section{The Africanist Critique and the Neo-Neo Synthesis}

Before elaborating on the Africanist critique - a mostly, but not exclusively, reflectivist movement - of the neo-neo synthesis, perhaps its critique of critical theory should be considered first. Africanists, in general, argue that Eurocentric in that it glorifies Western civilization via its identification of structures of exploitation (Hobson, 2007: 91-92). Moreover, by identifying structures of exploitation it essentially condones these structures by not offering a solution and consigning non-Western groups to the periphery, or groups or persons who do not conform to traditional Western culture (Hobson, 2007: 93). This assertion can be interpreted as being a misunderstanding of the nature of critical theory. The value of critical theory lies in its attempt to explain, or expose, structures of exploitation, and via this uncovering act as the foundation for emancipatory theories or movements, or at least the general improvement of the position of the marginalized. Critical theory's raison d'être - similarly to Marxism, 
which does offer an emancipatory theory - is to act as a voice for the marginalized and a champion for the elevation of the periphery.

The primary target of the Africanist critique is the neo-neo synthesis though. Africanists generally argue that the neo-neo synthesis cannot explain political realities in SSA and that the neo-neo synthesis allows for the exploitation of SSA by the West since the West has forced and is still forcing Western political concepts onto SSA (Neuman, 1998: 2). Africanists propose that the neo-neo notion of an international/domestic dichotomy where the international is characterized by anarchy and the domestic by a hierarchical nature where there exists a centralized state which permeates order is unfounded, and should be inverted in the case of SSA, implying that the notions of sovereignty, the market, one international system, the primacy of the state, rational choice theory, and all other concepts related to the Westphalian state system, are not applicable for the understanding of SSA political realities since it is argued that if these concepts are deconstructed then they were clearly designed for the European context (Neuman, 1998: 2-7; Vale et al, 2001: 11), and, moreover, that the centering of the neo-neo synthesis on great powers and superpowers naturally discount and thus marginalizes SSA and, furthermore, legitimizes exploitation by emphasising power politics (Ojo et al, 1985: 7-8, 11-13). Africanists argue that in the SSA political reality it is rather the international realm that is hierarchically ordered - since the international realm is dominated by great powers, or a superpower or superpowers, and influential NSAs (non-state actors) such as neo-liberalism would argue $\sim$ and that the domestic should be seen as anarchic and decentralized (Dunn, 2000: 64-66). The Africanist argument hence holds that SSA states are but nominally sovereign since they are perceived as lacking supreme authority over their territory and citizens and as being subject to the will of international regimes, international rules and norms, international organizations, and economic interdependence (Dunn, 2000: 64-75)

Africanists further argue that the possibility should not be discounted that more than one international system, characterized by unique practices and norms, can exist (Neuman, 1998: 3-5). The main target of the Africanist critique is hence the neo-neo synthesis emphasis on state as the primary unit or key unit, in the case of neo-liberalism, of analysis. Hence, it can be said that the Africanist critique is primarily a critique of neo-realism, not the neo-neo synthesis; and, certainly it has some credibility since certain theories within the realist tradition, such as 'alliance theory' do not offer much explanatory value (Neuman, 1998: 10-11). Africanists believe that one of the results of this nexus between the practical and theoretical has been the prescription of incorrect policies to SSA. For instance, the legal classification of SSA states as being sovereign makes them liable to debt and hence allows for their further exploitation and also leads to the implementation of policies such as SAPs (Structural Adjustment Programmes) (Dunn, 2000: 65-72) - both of which have fuelled the post-colonial arguments of still-existing structures of economic and intellectual colonialism. Indeed, the division of SSA during the Berlin Conference 1984-85 and the artificial, as opposed to the natural formation Europeans experienced, formation of states has had a lasting and detrimental effect on SSA, is a testimony to harm that can be done by external forces.

Africanists have thus argued that SSA should be divorced from mainstream IR theory and that a truly African IR theory should be constructed by African intellectuals, based on an intellectual return to some pre-colonial primordial SSA political reality (Dunn, 2001: 3-6; Vale et al, 2001: 27). The wisdom of such an endeavour and also the credibility of the Africanist critique have to be questioned however.

To turn to the evaluation of the Africanist critique, it can be argued that the Africanist critique is primarily a critique of neo-realisrn based on the adoption of neo-realist understandings of the concepts of 'anarchy', 'the state', and the 'international/domestic dichotomy' - in effect Africanists adopt neo-realist understandings of concepts to critique neo-realism. The Africanist critique does not consider neo-liberal, constructivist, and Marxist, to name but a few, understandings of the concepts of 'anarchy', 'the state', et cetera. The success of the Africanist critique is primarily based on its adoption of a neo-realist conceptualization - even its conceptualization of the reason for the generation of theory and the use of theory falls within the realist tradition - not to say that it does not enjoy some credibility. (Brown, 2006: 119)

Before elaborating on the aforementioned, it should be noted, as observed by Waltz, that theories are not intended to depict reality in its entirety, and should rather be seen as but simplifications that are intended to serve as the starting point of any analysis. Theories are but ideal types. (Brown, 2006: 124)

By employing the neo-realist notion of a Weberian state that is fully supreme, and therefore maintains full order over its territory and citizens, criticism of the applicability of the concept of 'the state' to SSA seemingly gains legitimacy. However, it should be noted that even neo-realists concede that no state - even in Europe, North America, and East Asia - has ever achieved full subjugation. Neo-realism's conception of the state as the only noteworthy unit is, admittedly, inapplicable to the SSA context though; but, not only the SSA context, it is inapplicable everywhere. Theories such as liberalism, Marxism, and constructivism, among others, recognize the 
state as being a key unit while simultaneously recognizing other units, such as NSAs, as playing a key role in the contemporary international system as well. For instance, Moravcsik, a prominent liberalist, argues that individuals and groups are the key actors, among other actors, and that they employ the state as an instrument for the attainment of their personal interest, which may lead to international interdependence; similarly, Marxism places emphasis on the internal/external nexus. Thus, by employing alternative - non-neo-realist - conceptions of the state, the concept of 'the state' remains applicable to the SSA context. (Brown, 2006: 133)

Furthermore, the Africanist critique rests on the rigid neo-realist international/domestic dichotomy and a misunderstanding of this dichotomy's relationship with the concepts of 'anarchy' and 'hierarchy'. The Africanist argument equates the anarchy/hierarchy dichotomy with the disorder/order dichotomy, which allows it to give a powerful critique of the neo-neo synthesis by arguing that, among other things, violence within SSA means that SSA states are anarchic; however, this criticism is unfounded since the neo-neo synthesis does not make this equation (Brown, 2006: 137). Waltz clearly distinguished between anarchy and disorder when he stated that anarchy merely refers to the absence of a centralized government in the international system characterized by mutual, and formal, recognition of states of each other's equality and sovereignty, and that disorder can be the result of fluctuations in the distribution of power (Brown, 2006: 137). Hence, disorder within SSA states does not imply that the formal hierarchical structure within the state ceases to exist; the hierarchical structure will continue to exist, at least nominally, as long as a legitimate authority continues to strive for its right to a monopoly of legitimate force (Brown, 2006: 137). Based on this misunderstanding of the concepts of 'anarchy' and 'hierarchy', Africanists assert that the international/domestic dichotomy is false in the way that the neo-neo synthesis envisions it. This assertion does not merely lack credibility due to its questionable understanding of key concepts, it also lacks credibility in that the neo-neo synthesis's focus on great powers and superpowers and, in the case of neo-liberalism, NSA and other international phenomena such as interdependence naturally implies that a hierarchical structure would be formed within an anarchical international system (Brown, 2006: 138). Indeed, IR theories in general - positivist or post-positivist - recognize this hierarchical structure (Brown, 2006: 138). It is only by employing neo-realism's semi-rigid equation of the international/domestic dichotomy equation with the anarchy/hierarchy dichotomy, which is the most flawed of modern IR theories, that the Africanist critique gains some legitimacy.

Moreover, it should be noted that the Africanist critique is only effective when using extreme examples such as Liberia, Sierra Leone, and Somalia - all of which come, or came, close to being a Hobbesian nightmare (Brown, 2006: 135). When using less extreme examples, such as Botswana, the Africanist critique loses credibility. However, even when extreme examples are used, mainstream IR theories such as neo-liberalism, Marxism, and critical theory do go a considerable way in explaining phenomena within such extreme examples by giving regard to the domestic, NSAs, and transnational movements and phenomena (Brown, 2006: 133-134); subaltern realism is also particularly useful due to its assumption of the link between domestic order and international order and emphasis on issues of domestic order and conflict, their relation to external influences, and linkage between the domestic and external, which explains intra- and inter-state conflict to some extent (Neuman, 1998: 45), however it does not escape the neo-realist tradition, or its conceptualization to be specific (Smith, 2006; 5). Naturally some theories within the various traditions are inapplicable to SSA, such as 'alliance theory', but this should not be interpreted as some incompatibility of mainstream IR theories with SSA. It is rather SSA's lack of socio-cultural and socio-economic development that has made certain theories within mainstream traditions incompatible with SSA.

\section{The Africanist Delusion \& Mainstream International Relations Theories}

Mainstream IR theories, in general, continue to be of some value because they are based on humans' understanding of the notions of care and harm, fairness and reciprocity, authority and respect, ingroup and loyalty, and purity and sanctity, as argued by Haidt (2007: 9 98-1001), a prominent evolutionary psychologist. To elaborate, Haidt (2007: 998-1001) argued that humans are not born tabula rasa and are born with an understanding of the aforementioned notions. He argued that conservatives value the latter three notions the most highly while liberals value the former two the most (Haidt, 2007: 998-1001); hence the universal prevalence of these notions implies that even though concepts such as 'democracy' and 'the state', to name but two, are at times understood differently in Asia and SSA, mainstream IR theories are still applicable since a universal fundamental human nature is still found within these regions. It can be argued that these values would have given rise to mainstream IR theories within any civilization once they achieved a certain stage of development and developed an understanding of 'the international'. It should hence not be surprising that Kim Dae-jung identified pre Lockean liberal strands - such as the ancient Chinese philosophy of Minben Zhengchi and the Korean religion of Tonghak - of thinking within the writings of classical scholars in Asia in response to Lee Kuan Yew's claim that "Western concepts" such as democracy and human rights are incompatible with Asia (Kim, 1994), an argument buttressed by de Bary's (1983) The Liberal Tradition in China; similarly, strands of realism could be identified within the thought of China's Shang Tzu and Han Fei-tzu and 
India's Kautilya (Smith, 2008: 4). The development of mainstream IR theories is dependent on Hegelian-like process - if Kojeve's Thymos-centered interpretation is employed, where the desire for recognition is the motor of history - of socio-cultural, economic, and political development - Fukuyama famously argued that liberal democracy is the end of history, in terms of ideas, as dictated by the Thymos dynamic. To comment on post-positivist, constitutive theories such as feminism and green theory, these theories only become broadly applicable in societies which have achieved a stage of advanced socio-cultural, political, and economic development where, in the case of the contemporary world, liberal democracy is embraced, which has not occurred yet in SSA, with this embracing of liberal democracy subsequently leading to different kinds of questions - mainly because liberal democracy has a certain relativism associated with it - due to Thymos dynamic (Fukuyama, 2006: 332); it is then when Nietzsche's use of Thymos in his conceptualization of the Übermensch takes effect (Fukuyama, 2006: 332-335) and post-positivist, constitutive theories such as feminism gain substantial relevance. It is only via external influence that post-positivist theories have gained a hold in SSA. Mainstream IR theories such as those within the realist, liberal, and Marxist tradition are hence more relevant for understanding SSA since they are based, attuned, to more primitive human socio-cultural and socio-economic development than post-positivist, constitutive theories such as feminism. Green theory, feminist theory, and Critical Theory in general may be invaluable in explaining the situation that SSA finds itself within, but a truly African IR theory would not be able to base itself on any of the aforementioned since it lacks the socio-cultural, economic, and political Weltanschauung associated with the aforementioned post-positivist theories. An truly African IR theory would only really be able to adopt bits and pieces, although if the notion of the power-knowledge nexus is strictly adhered to the aforementioned post-positive, constitutive theories may be too Western to act as the foundation of an African IR theory that might put SSA - and its issues - at the centre of the international political, social, and economic world.

The Africanist critique is founded upon the notion of extreme relativism - a notion which was discredited long ago in the dialogues, as recounted by Plato, between Protagoras, Theodorus, and Socrates - and is essentially a romantic, and perhaps even fashionable, movement. If the Africanist critique were to gain widespread legitimacy, if it could affect SSA adversely in that it could lead to the further marginalization of SSA (Brown, 2006: 141-142). Žižek (Myers, 2003: 104) illustrates this logic by asking rhetorically logic by asking rhetorically "Was not the official argument for apartheid in old South Africa that black culture should be preserved in its uniqueness, not dissipated in the Western melting-pot?" Similarly, British colonial officials argued that Africans had different political systems than those in the West and that Africans were thus not suited to living in the modern world, and that African societies should hence be guarded from modernization, urbanization, and industrialization and rather be left to developed "naturally" in an African way without any foreign control (Brown, 2006: 141-142). Undoubtedly, SSA societies would, like all other societies, have desired industrialization and modernization, in the Western sense, even if they did not experience colonization. Moreover, by arguing that theories should be developed which allow state, economic, and social breakdown as well as warlordism, inter alia, to gain acceptance, as opposed to a healthy functioning state with adequate social and economic conditions, it would logically lead to the further marginalization of SSA in world politics and the global economy (Brown, 2006: 135-136).

Furthermore, if an intellectual return, as some Africanists desire, to an "unpolluted" primordial pre-colonial SSA were possible, it is highly unlikely that the Weltanschauung uncovered would be able to act as a foundation for the creation of a truly African IR theory - assuming it possible - since the pre-colonial Weltanschauung did not have an understanding of the international as it is understood in the present since it was an age of tribalism and chiefdoms and no state systems existed, which would make any hypothetical African IR theory incompatible, and even contradictory, with the modern international system.

If mainstream IR theories truly did marginalize, then it would be inconceivable that Japan, the East Asian Tigers, and, contemporaneously, China could experience rapid rates of development, while the West in, contemporarily, in decline. It can be argued that both Japan and South Korea experienced a process of substantial Horizontverschmelzung via, some would argue, globalization (Acharya \& Buzan, 2007: 300), but this is not true for a state such as China. Post-colonialism, and similar theories, hence have limited value. Mainstream IR theories do not marginalize SSA; it is rather the post-colonial governments of SSA that have led SSA to its marginalized status due to the anti-developmental Weltanschauung of the post-colonial SSA governments in general. Idealistically, only a development-minded practical, as opposed to being ideologically rigid, government and active and engaged positive citizenry can rescue SSA from its marginalized status, as indicated by the 2009 Dinokeng Scenarios report. Nevertheless, there are certainly some unique phenomena and dynamics within SSA that mainstream IR theories have difficulty in explaining, mainly due to SSA's unique social, political, intellectual, cultural, geographical, ideological, and historical context which has led to a different Weltanschauung. Furthermore, colonialism doubtlessly had, and is still having, adverse effects on SSA. However, SSA can use its unique context to improve 
concepts such as 'the state', via a Gadamerian dialectic of Horizontverschmelzung between positivist and post-positivist IR theories and Africans, within IR theories and hence constructivism, as an approach, might be of some aid to SSA's plight; constructivism should not be taken as a substitute for mainstream IR theories such as neo-realism and neo-liberalism, both of which are embedded in human nature.

To illustrate the continued relevance of the realist tradition - since the realist tradition has been the primary target of the Africanist assault - in the contemporary international system, Thayer's (2010) article entitled The Continued Relevance of Realism in the Age of Obama: Plus Ça Change, Plus C'est La Même Chose merely needs to be considered. Thayer (2010: 2-3) observed in the aforementioned article that, despite being the most leftist president to be elected, Barack Obama's Modus Operandi falls within the realist tradition. Before substantiating the aforementioned, the following quotes drawn from Thayer's $(2010: 1,2)$ article should be considered as a warning of the danger of academic fads:

President Barack Obama is no different. Every new president comes to office pledging to break with the past and to conduct international politics with principle and morality. Each administration claims that it will bring new ideas to international politics and will not only break with the failed policies of its predecessor but will also lead the United States and the world to a new, brighter future while solving the problems the country faces and reducing the dangers. Such idealism is not limited to presidents. Any review of foreign policy magazines will show that there is no shortage of brighter paths and new theories in international politics touting the flatness of the world in the era of globalization or why international politics must "go green" to save the earth from disasters.

At every inaugural and among the punditry pontificating in the colorful magazines, it seems no one is a realist as in the past... At least no politician or commentator is a realist in his rhetoric. Yet once the glow and honeyed words of the inauguration are past and the administration actually has to advance America's interests, the mask slips in deeds if not in rhetoric, and realism is reborn. In fact, it never went away.

In academic and policy circles, it is fashionable to criticize realism.

Thayer (2010: 1-2) argues that the contemporary realist tradition can be identified with four verities, namely, that (a) "power is the component of international politics, and that states have to seek power to survive"; (b) "a state's national interests are primary and must be advanced in all circumstances and by all means at the state's disposal, through economic, military, and diplomatic means, by both hard and soft power"; (c) "a state can depend on or trust no other states, and cooperation, such as alliances, is always contingent", lasting only as long as interests coincide; and, (d) that "international politics as it is, governed by the pursuit of power and self-interest and by a lack of trust that makes cooperation contingent rather than as we would wish it to be, a world of trust, cooperation, and altruism". Naturally, the state is considered the dominant actor of world politics (Dunne \& Schmidt, 2008: 103).

Thayer (2010: 3) reveals the realist nature of the Obama administration by, firstly, analyzing the issue of Iran's attempt to acquire nuclear weapons and the nature of the issue vis-à-vis the United States (US). Thayer (2010: 3) posits that Iran is attempting to acquire nuclear weapons for "good realist reasons" - the possession of nuclear weapons would act as a significant deterrent to the US and Israel in particular - and that, similarly, the Obama administration is attempting to prevent Iran from acquiring nuclear weapons for "good realist reasons" - an Iran with nuclear weapons would, (a) significantly lessen the US's ability to coerce Iran, (b) threaten the US's interests and in the Persian Gulf region, and (c) possibly act as a "proliferation conduit" in the future. Thayer (2010: 3) further argues that the Obama administration has come to the realization that it is inevitable that Iran will acquire nuclear weapons and has hence begun adjusting alliances and its military force structure in the region.

Thayer (2010: 3) secondly, as a continuation of the issue discussed in the previous paragraph, analyses the Obama's administration's decision refrain from deploying ground-based interceptors in Poland and a power radar in the Czech Republic and posits that this decision was highly realist in that the Obama administration rather opted to deploy the aforementioned weaponry in such a way to prepare for a confrontation with Iran, and hence the Obama administration has opted to deploy mobile sea-based platforms in the eastern Mediterranean and ground-based platforms in Europe and Turkey - a system buttressed by an existing US radar in Israel and one that is soon to be deployed in the Caucasus. Obama's missile defense system has been deployed in the aforementioned manner in order to increase the likelihood that missiles launched from Iran "will be intercepted in their boost phase, thus blowing up over Iran" (Thayer, 2010: 3).

Thirdly, Thayer (2010: 3) observes that the Obama administration's policies in Iraq are essentially a continuation of those of the Bush administration, with the Obama administration rescinding Obama's election promise of withdrawing from Iraq; and, moreover, the Obama administration policies in Afghanistan are "out-Bushing Bush" (Thayer, 2010: 3), with the Obama administration continuing to support the Hamid Karzai government and "surging forces into that country as it accelerates covert action programs in Afghanistan and Pakistan" (Thayer, 2010: 3). 
Fourthly, and finally, Thayer (2010: 3) notes that politics vis-à-vis great powers such as China and Russia have not changed significantly. Thayer (2010: 3) argues that the Obama administration continues to view Moscow a "healthy suspicion", yet recognizes - in the same way that the Bush administration did - that Russia's support is crucial in a number of key issues - such as that of terrorism, piracy, North Korea, et cetera. Furthermore, Thayer (2010: 3-4) posits that both the US and Russia have a shared interest vis-à-vis China in the sense that the rise of China will represented as a common threat - lead to greater cooperation between the US and Russia - such as reflected by the Obama administration's decision to abandon the European missile site and, furthermore, the indifference of the Obama administration with regard to Georgia's attempt to join NATO (North Atlantic Treaty Organization). Thayer (2010: 4) moreover argues that the Obama administration's continuation of the Bush administration's support of a two-China policy - as revealed by the arms sales to Taiwan - with the rationale being that a "divided China is a weaker one", with the Obama administration notably - or rather unnoticeable due to its gradualism - (a) expanding the presence of the US naval and air force in the Western Pacific in order to attempt to cover US vulnerabilities vis-à-vis China in the Western Pacific, and (b) creating a network of alliances with states which border China - there is either a US military presence in or military cooperation with Afghanistan, India, Japan, Kazakhstan, South Korea, Mongolia, and Vietnam. Thayer (2010: 4) notes that the "Obama administration continues the policies of the last three American presidents" in preparing for a possible Sino-American confrontation - however unlikely. The Obama administration's position vis-à-vis North Korea can be understood in a similar light.

\section{Conclusion}

Hence, although Africanists, postmodern theorists, and critical theorists, inter alia, may argue that globalization is tied to Westernization and, more specifically, Americanization, this is precisely the point. Dunne and Schmidt (2008: 103) note that "globalization should not be seen as a process that is disconnected from the distribution of power in the international system". Hence, it should not be surprising that the US has been a passionate supported of the core values of globalization - namely, liberalism, capitalism, and consumerism - given the position of the US within the international system (Dunne \& Schmidt, 2008: 103). Moreover, the realist nature of the behaviour of states hence implies that the liberal hope of "dissolving the boundaries of difference among the peoples of the world" is ill-founded (Dunne \& Schmidt, 2008: 104). Realist theory does not - as some of the aforementioned theories would hold - lead to an international system which marginalizes SSA, rather, the realist tradition acts in a descriptive manner to explain SSA's marginalization. This marginalization cannot be overturned through the mere imagining of alternate realities and through this the hope of introducing new norms for this notion acts as a contradiction to human nature, as discussed by Haidt. It needs to be understood, though, that the claim being made is not that the realist tradition is complete - in an explanatory sense since the realist tradition cannot explain all phenomena, as highlighted by theories such as constructivism and the constructivist understanding of Homo Sociologicus, as opposed to the realist adherence to the notion of Homo Economicus - and that other theories should be disregarded, but rather that the realist tradition should be given more credit and not be so easily vilified. It should furthermore not be forgotten that the realist tradition is highly moral.

This is not to say that the Africanist position is invalid. It does raise some important issues. However, the Africanist position cannot be taken seriously in its attempt to discredit and vilify the neo-neo synthesis.

\section{References}

Acharya, A., \& Buzan, B. (2007). Why is there no non-Western international relations theory? An introduction. International Relations of the Asia-Pacific, 7(3), 287-312.

Brown, W. (2006). Africa and international relations: a comment on IR theory, anarchy and statehood. Review of International Studies, 32, 119-143.

De Bary, W. D. (1983). The Liberal Tradition in China. New York: Columbia University Press.

Dinokeng Scenarios. (2009). Dinokeng Scenarios - Full Report. [Online] Accessed http://www.dinokengscenarios.co.za/pdfs/book small.pdf (August 2, 2009)

Dunn, K. C. (2000). Tales from the dark side: Africa's challenge to international relations theory. Journal of Third World Studies, 17(1), 61-91.

Dunn, K. C. (2001). Introduction: Africa and International Relations Theory. In Dunn, K.C. \& Shaw, T.M. (eds.). Africa's challenge to international relations theory. Houndmills: Palgrave, (Chapter 1).

Dunn, T. \& Schmidt, B. C. (2008). Realism. In Baylis, J. (ed.). The globalization of world politics: an introduction to international relations ( $4^{\text {th }}$ ed.). New York: Oxford University Press, (Chapter 5). 
Fukuyama, F. (2006). Immense Wars of the Spirit. The End of History and the Last Man ( $2^{\text {nd }}$ ed.). New York: Free Press, (Chapter 31).

Haidt, J.( 2007). The New Synthesis in Moral Psychology. Science, 316, 998-1001.

Hobson, J. M. (2007). Is critical theory always for the white West and for Western imperialism? Beyond Westphalian towards a post-racist critical IR. Review of International Studies, 33, 91-116.

Kim, D. J. (1994). Is Culture Destiny? The Myth of Asia's Anti-Democratic Values. Foreign Affairs, 73(6), 189-194.

Myers, T.( 2003). Why is racism always a fantasy? In Slavoj Žižek. New York: Routledge, (Chapter 6).

Neuman, S. G. (ed.). (1998). International relations theory and the third world. London: Macmillan.

Ojo, O. J. C. B., Orwa, D. K. \& Utete, C. M. B. (1985). Theories of international relations. In African international relations. London: Macmillan, (Chapter 1).

Smith, K. (2006). Can it be Home-Grown? Challenges to Developing IR Theory in the Global South. Paper presented at the International Studies Association's 47th Annual Convention, San Diego 22-25 March.

Smith, K. (2008). Has Africa got anything to say? African contributions to the theoretical development of International Relations: A Preliminary Investigation. Paper presented at the BIZA Africa and IS workshop, Milton Keynes, 9 July.

Thayer, B. A.( 2010). The Continued Relevance of Realism in the Age of Obama: Plus Ça Change, Plus C'est La Même Chose. American Foreign Policy Interests, 32(1), 1-4.

Vale, P., Swatuk, L. A. \& Oden, B.( 2001). Theory, change, and Southern Africa's future. Houndmills: Palgrave. 